\title{
DICKENS'S CONSUMPTIVE URBANITY: CONSUMPTION (TUBERCULOSIS) THROUGH THE PRISM OF VICTORIAN SENSIBILITY ${ }^{1}$
}

\author{
Hristo Boev \\ Department of English Studies, \\ Konstantin Preslavsky University of Shumen, Shumen, Bulgaria
}

\begin{abstract}
This article examines the correlation between consumption and tuberculosis in Dickens's city, tracing the evolution of its representations in his novels. It compares these representations to the coverage of the disease in Victorian newspapers against criticism on tuberculosis and literature. In so doing, the article establishes Dickens as a writer divided by his scientific approach as a city life chronicler and his Victorian imagination. Since consumption and consumerism as a phenomenon appeared in the mid-19th century, the text also aims to determine the dimensions of the interaction between consuming the city and being consumed by it and how this is related to tuberculosis. The researched material includes early to mid-Dickens's works since tubercular presence is the strongest felt and the most significant there; thus, consumption (tuberculosis) in Dickens can be considered the Janus face of early consumerism, resulting from insufficient consumption of food and proper care.
\end{abstract}

Key words: tuberculosis, consumption, urban, disease, Victorian

\begin{abstract}
About the author: Hristo Boev, Ph.D. is a senior assistant professor of English and American Literature at the Faculty of Humanities, University of Shumen, Bulgaria. He is the author of the books: Modern(ist) Portrayals of the City in Dickens and Dos Passos: Similarities, Differences, Continuities, The Different Dobruja in the Literature between the Wars (original title in Bulgarian) and Feminine Selves in Sylvia Plath's Prose and Poetry: The Perspective of Compared Lived Experience in Fiction. He is also a translator of English and Romanian with numerous literary translations to his credit. His main interests lie in the fields of Comparative Literature, Modernism, Literary Urbanism, Geocriticism, Phenomenology of Perception and the Art of translation.
\end{abstract}

e-mail:h.boev@shu.bg;

ORCID ID: https://orcid.org/0000-0002-6933-3167

Copyright $\odot 2021$ Hristo Boev

Article history: Received: 25 July 2021; Reviewed: 12 October 2021; Revised: 15 October 2021; Accepted: 16 October 2021; Published: November 2021

This open access article is published and distributed under a Creative Commons Attribution 4.0 International License.

Citation (APA): Boev, H. (2021). Dickens's Consumptive Urbanity: Consumption (Tuberculosis) through the Prism of Victorian Sensibility. Studies in Linguistics, Culture, and FLT, 9(3), 32-43. https://doi.org/10.46687/ LKRM1771.

1. Originally published by Victorian Web with the title: "Dickens's Consumptive Urbanity: Consumption (Tuberculosis) through the Prism of Sensibility". Publishing the article here is done with the kind permission of the original publisher $-\mathrm{a} . \mathrm{n}$. 
Life in big Victorian cities was very different from life in small towns or villages. It demanded a stronger immunity on part of the city dwellers to all sorts of pollution as their senses were overwhelmed by the batteries of sound, all-pervasive smog, contaminated potable water and advertisements urging them to continue consuming despite the big city's notorious bad weather, which might affect a consumer's disposition. This article examines a wasteful disease associated with consuming the city in Dickens's represented spaces tuberculosis also called tb for short and its early name - consumption alluding to the fact that the sufferers from this disease were very visibly consumed by it, which eventually led to their physical dissolution. This article also establishes the relationship between city consumption and tuberculosis in Dickens's urban representations.

Undoubtedly, there exists a relationship between consumption in the city at the end of the nineteenth and beginning of the twentieth centuries and consumption, the disease that was a scourge wiping out thousands of lives during the Victorian period. Extreme consumption has all the symptoms of a terminal disease in Dickens's represented spaces. The interrelation between the consumer and the modern city appears in the city dweller's consuming the city - consumption of commodities, and him or her being consumed by it in return - consumption as the medical condition found in the modern city inhabitants' succumbing to the forces sapping their energy while trying to generate means of survival in the metropolis, meeting its costs and paying for them with their health. Indeed, the Victorian city's heavily polluted air and contaminated water caused many pandemics. Some of the diseases causing them could easily be connected to nineteenth-century modern urbanity - cholera, tuberculosis, and typhus, which resulted from consuming contaminated water and food products, breathing polluted metropolitan air, and chronic malnourishment of the poorest class of city dwellers. Not by chance people who had tuberculosis at the time were advised to leave the cities they lived in as soon as possible. According to Alan Robinson's Imagining London 1770-1900 (2004), the concern with public hygiene in Victorian London reflected the very real and recurrent threat of cholera: there were major epidemics in 1832, 1849, 1854 and 1866. Typhus, typhoid fever, tuberculosis, and smallpox were principally diseases of the poor, exacerbated by overcrowding, poor diet, and insanitation; cholera was the great leveler that struck all classes alike. It may have caused fewer deaths, but it literally brought home the public health problem to the middle classes (Robinson, 2004, p. 54). In numerous reports in the Victorian press, consumption in its most frequent form at the time, pulmonary tuberculosis, was associated with everyday metropolitan life in overcrowded residential areas known as rookeries where many tenants regardless of sex or age occupied the same room so they could pay a lower rent. The narrow city streets where peddlers, residents and transient travelers would rub shoulders also increased the spread of the air-borne tubercular infection. 
Urban novelists, such as Dickens, felt strongly about the issue, and aiming at a truthful representation of urban life, featured ample examples of the devastation this disease brought on the afflicted city dwellers. In corroboration of the data presented by several Victorian newspapers, Dickens also lays the blame on the poor sanitary conditions of London slums at the time as well as the general poverty of the city residents whose only choice for a residence were the tenement buildings (rookeries). Unlike the newspapers, however, which more often than not assumed a neutral tone referring to statistical data of the numbers of the fatalities from the disease, Dickens establishes a direct connection to its cause, which he sees in insufficient urban consumption.

Novels that could serve as case studies of consumption in both senses of the word are from the period 1836-1848 and appear in a chronological order: Sketches by Boz (2009), Nicholas Nickleby (1990), The Old Curiosity Shop (1907), A Christmas Carol (2006), and Dombey and Son (2009). An argument will be made that the tubercular look, resulting from insufficient corporeal consumption, could be related to the image of the emerging modern man as well as to spirituality in Dickens's later works such as David Copperfield (1998), Little Dorrit (1868) and Great Expectations (1993). The English writer's first take on the subject in Sketches by Boz, as we shall see, is wonderfully free of Victorian morality and contains an early modernist irony where tuberculosis cannot be related to any lofty metaphors of perceived redemption or embellishment which appear as early as Dickens's Nicholas Nickleby and which can be related to Victorian sensibilities. In all his works where the disease plays a role, regardless of its metaphorical load, the setting is the big city.

The following passages and more appeared in Victorian newspapers, which viewed pulmonary tuberculosis as a daily companion to city life and chronicled the toll it took. Unlike Dickens's representations of the disease, these journalist accounts are more closely related to statistics than to establishing correlations with the urban condition with occasional comments on causes and effects. There are many, advertising wondrous medications that supposedly can cure the patients of their affliction. The ones that offer us the statistics are grisly enough in the sheer numbers of deaths revealing pulmonary tuberculosis as a scourge endemic of the modern city:

Mortality in the Metropolis. - The weekly return continues to exhibit a satisfactory state of public health. The deaths, which were about 1,200 towards the end of last month, have fallen in the last week to 1,048 or 121 less than the average. The mortality from epidemics, with the exception of hooping cough, is little more than the average, and has fallen twenty-five per cent within the period of the month. The mortality caused by small-pox and measles is still unusually low; and that from scarlatina is now little more than the average. Diarrhoea has declined; and the deaths from cholera are only 10,9 of which as is shown below, occurred in one workhouse and two hospitals; three in one family. Scarlatina and typhus were each fatal to 40 persons, which is rather less than the average for the latter 
disease. Inflammation of the lungs and air passages, and pulmonary consumption, do not prevail fatally at the present time: the aggregate deaths in the week from these diseases were only 260, whereas the average is 329. (The Northern Star and National Trades'Journal, Leeds, England, Saturday, March 31, 1849; Issue 597, p. 1)

As we learn from the passage above, the statistics presented should be understood as optimistic by comparison with a striking average number of metropolitan deaths per week, which prompted the conclusion made by the journalists of those times that this state of public health should be considered satisfactory. Another passage offering statistical mortality rates in London 11 years later does not reveal an improvement in these black numbers:

In great part of the week that ended on the 10th instant the air was exceedingly cold; it continued cold in a less degree till neat the end of last week, and the London returns exhibit a consequent increase in the mortality. The deaths, which had declined to 1,397, rose again to 1,563 in the week that ended last Saturday. In the ten years 1850-59 the average number of deaths in the weeks corresponding with last week corrected for increase of population, is 1,362 . The deaths of last week were therefore in excess of the number by 201. By comparing the results of the last two weeks it appears that the deaths by bronchitis rose from 230 to 267; those by pneumonia from 114 to 140 those by asthma from 20 to 27. Phthisis, or pulmonary consumption, which carried off 143 persons in the previous week, was fatal last week to 171. (Lloyd's Weekly Newspaper, London, England, Sunday, March 25, 1860; Issue 905, p.1)

As the passage eloquently claims, pulmonary consumption alone caused the death of 314 city residents of a metropolis with a population of over 2 million people in the 2 weeks analyzed. When discussing the causes of the analyzed disease of the modern city, health officials, journalists, and other investigators invariably attributed it to the very bad sanitary conditions in which the city dwellers lived:

A little further up the street there is a house consisting of two storys [sic] and entering from a close one of the most wretched, rickety fabrics imaginable, filled with filth, dirt and smoke. The apartments, small miserable holes, are seven in number, and occupied by as many families. A few weeks ago, four of these families were afflicted with fever at the same time - in one four females were lying together, in another one girl, in a third, a mother and two children, in a fourth, a mother and two daughters, and in a fifth house, an old man in an advanced stage of pulmonary consumption. (The Newcastle Courant, Newcastleupon-Tyne, England, Friday, November 10, 1843; Issue 8814, p. 1)

This description is concordant with similar depictions of mass attacks of tuberculosis related to poor urban residential conditions made by Dickens in the passages that I shall analyze below. These depictions are especially numerous in Sketches by Boz (2009) and Nicholas Nickleby (1990) also featuring Dickens's sympathetic commentaries towards the sufferers. As it is well known, a definitive cure for the disease was not found until the early 1940s when streptomycin, the first antibiotic effective against tuberculosis, was discovered. 
The laissez-faire economy during the epoch created what was perceived as a three-tiered society where Veblen's term of conspicuous consumption (The Theory of the Leisure Class, 2007) usefully described high consumerism. The lowermost position was for the working class - men and women occupied with physical work - "productive labor" (Veblen, 2007, p. 28), whose effects could be seen on the workers' clothes - worn off and dirty, receiving daily or weekly wages. The middle class were next, who did mostly clean work - mental, not physical and were paid a monthly or a yearly salary. Finally came the elite or upper classes that did not work for money: the aristocracy or landed gentry, their income coming from inherited land or investments (Mitchell, 2009, p. 18). As Dickens places a strong emphasis on consumption in his represented urban spaces, tuberculosis (consumption) could not just be deemed an aspect of the larger economic phenomenon as it not infrequently blends with it, simply being the other name of deficient consumption in the city. It was very common among the poor city inhabitants, and we can argue that the Dickensian punishment for excessive consumption befalling high-class consumers such as Mr. Dorrit, who miraculously inherits a large fortune and tries to live up to his new parvenu status, Mr. Merdle, who deals in fraudulent investments and who is to blame for Mr. Dorrit's bankruptcy, Mrs Clennam, who is confined to a wheelchair, is the keeper of the secret to the Dorrits' fortune and lives in a dilapidated mansion (Little Dorrit, 1868), is equally relentless. Together with Miss Havisham, who like Mrs Clennam lives in a big house, is cold, cruel, and miserly (Great Expectations, 1993), they are rich enough and not working. However, they are all guilty of conspicuous consumption and their capital punishment is an attempt at achieving a wondrous equilibrium of victims of consumption (tuberculosis) among the poor and the rich in both senses - consuming the city as in extreme consumption of commodities and being consumed by it as in falling victim to consumption (tuberculosis). We can also argue that excessive economic consumption in Dickens's urban representations of which Mr. Dorrit and Mr. Merdle are prime examples is penalized by being transmogrified into a mental illness that doctors cannot diagnose and that has a lethal prognosis, thus restoring consumption equality. Unlike wealthy urban consumers, city inhabitants who suffered from consumption-as-disease could be diagnosed but not helped - a major difference from the extreme urban consumers, who are represented as suffering from the disease of commodity or business consumption, but the symptomology of this disease remains hidden to public scrutiny as illustrated in Mr. Merdle's mysterious medical condition in Little Dorrit (1868) from 1857. Consequently, Dickensian justice is exercised in secret.

In Illness as Metaphor, and AIDS and Its Metaphors (2001) Sontag establishes a connection between tuberculosis as an illness of the lungs and, consequently, as an illness of the spirit as represented by the romantic imagination. According to her, the respiratory activity of the lungs and the flesh break down to water and 
phlegm, thus turning into a spirit - the lungs belonging to the upper (superior) body parts, prioritizing the spiritual over the corporeal - unlike cancer, which attacks the lower parts, and is consequently unromantic (Sontag, 2001, p. 22). She also argues that it is a disease related to poverty, and if not always related to the standard of living, sometimes connected to poverty of the spirit, e.g., Marguerite from La dame aux Camélias (2016) by Dumas-fils, or Paul Dombey from Dombey and Son, books released in the same year - 1848. Being an illness of the lungs, tuberculosis is commonly associated with dank and dirty cities, hence the physician's advice from Nicholas Nickleby (1990) given to Smike to leave London at once.

Early works representing tuberculosis in the city, such as Sketches by Boz from 1836 and The Old Curiosity Shop from 1841 manifest an ambivalent view that sees tuberculosis both as an indiscriminate killer regardless of sex, age, or financial means, and as a scavenging urban agent that has a predilection for the minimal consumers of the city - the very poor, who are consumed by the metropolis and to whom consumption (tuberculosis) acts as an allegory of the indifference of the modern city towards its inhabitants. The city, which has accumulated the synergy of all its residents, consumes them in turn, dispensing with the most vulnerable ones. In other words, the city is seen as a monster fed by and feeding off its inhabitants. Later, a more mature work such as Dombey and Son (2009) from 1848 accentuates the spiritual character of tuberculosis, which is related to a perceived mythologizing of the disease in fiction during the Romantic period and the Victorian Age as demonstrated by Susan Sontag in her Illness as Metaphor and AIDS and Its Metaphors (2001), and which allegorizes innocence. Finally, in its antithetic representation synonymous with consumption and at the same time its negation, tuberculosis underscores the pathology of capitalism of the modern city as represented by Dickens.

An example of tuberculosis as an indifferent killer appears in the following description from Sketches by Boz in the depiction of the consumptive curate whose love for religion and the spiritual is at variance with the demands of the metropolis on his body, so that religious asceticism is refuted by corporeal needs through the vehicle of tuberculosis:

One would have supposed that, by this time, the theme of universal admiration was lifted to the very pinnacle of popularity. No such thing. The curate began to cough; four fits of coughing one morning between the Litany and the Epistle, and five in the afternoon service. Here was a discovery - the curate was consumptive. How interestingly melancholy! If the young ladies were energetic before, their sympathy and solicitude now knew no bounds. Such a man as the curate- such a dear-such a perfect love - to be consumptive! It was too much. Anonymous presents of black-currant jam, and lozenges, elastic waistcoats, bosom friends, and warm stockings, poured in upon the curate until he was as completely fitted out with winter clothing, as if he were on the verge of an expedition to the North Pole: verbal bulletins of the state of his health were circulated throughout the 
parish half-a-dozen times a day; and the curate was in the very zenith of his popularity (Dickens, 2009, pp. 10-11).

If one may be tempted to see tuberculosis as a punishment for the curate's vanity and his consumption of anonymous presents, one should read further and see that in this book of Dickens's urban consumption and its pathological form of tuberculosis is extended to all weak members of the metropolis, appearing even in the consumptive donkey as a beast of burden: "Covent-garden market, and the avenues leading to it, are thronged with carts of all sorts, sizes, and descriptions, from the heavy lumbering waggon, with its four stout horses, to the jingling costermonger's cart, with its consumptive donkey" (Dickens, 2009, p. 59). When it comes to portraying tuberculosis in the minimal consumers of the metropolis, Dickens's early modernist irony of a detached observer unconcerned with the romantic representations of tubercular sufferers gives way to passing remarks of Victorian sympathy:

This eloquent address produces anything but the effect desired; the women rail in concert; the man hits about him in all directions, and is in the act of establishing an indisputable claim to gratuitous lodgings for the night, when the entrance of his wife, a wretched, worn-out woman, apparently in the last stage of consumption, whose face bears evident marks of recent ill-usage, and whose strength seems hardly equal to the burden — light enough, God knows! — of the thin, sickly child she carries in her arms, turns his cowardly rage in a safer direction. 'Come home, dear,' cries the miserable creature, in an imploring tone; 'Do come home, there's a good fellow, and go to bed.' Go home yourself,' rejoins the furious ruffian. (Dickens, 2009, p. 194).

The passage above portrays London's inhabitants in naturalist terms contending for places of habitation, the weakest members consumed by tuberculosis. Dickens's approach is scientific observing details of the ravages of the disease and the impact left by the husband (marks of recent ill-usage, in the last stage of consumption, natural protector), but at the same time humane, commiserating with the plight of the afflicted with tuberculosis (a wretched worn-out woman, miserable creature). The insensitive husband is called "furious ruffian", thus subjective comments are made to the otherwise naturalist representation of contended city space.

Dickens's depictions of tuberculosis range from the sarcastic and ironic (the curate) through the sympathetic (the poor woman from the passage above) to the deeply philosophical and spiritual as the following passage from Nicholas Nickleby (1990) from 1839 will show:

There is a dread disease which so prepares its victim, as it were, for death; which so refines it of its grosser aspect, and throws around familiar looks unearthly indications of the coming change; a dread disease, in which the struggle between soul and body is so gradual, quiet, and solemn, and the result so sure, that day by day, and grain by grain, the mortal part wastes and withers away, so that the spirit grows light and sanguine with its lightening load, and, feeling immortality at 
hand, deems it but a new term of mortal life; a disease in which death and life are so strangely blended, that death takes the glow and hue of life, and life the gaunt and grisly form of death; a disease which medicine never cured, wealth never warded off, or poverty could boast exemption from; which sometimes moves in giant strides, and sometimes at a tardy sluggish pace, but, slow or quick, is ever sure and certain (Dickens, 1990, p. 637).

This passage shows that those afflicted by the disease can be seen as being cleansed of consumption in preparation for passing away. The concept expressed here shows a duality resulting from the dreaded onset of the medical condition and the solemn reinstatement of the spirit over the consumptive body. Tuberculosis as an extreme form of consumption (wasting) of the body prepares the spirit for another mortal term until it can be freed into a pure personification of innocence (Boev, 2011). The transformations of the body in its passage to death is seen as indicative of the fact that urban consumption in all its forms can be ultimately interpreted as conductive to death, the more extreme it is, the faster death sets in. I continue my analysis by examining the consumptive space in A Christmas Carol (2006) from 1843, revealing Dickens's idea of urban consumption as instrumental in the onset of and subsequent recovery from supposed bone tuberculosis. This pattern appears in opposition of the city dweller Tiny Tim to the cold harshness of Ebenezer Scrooge, who represents, almost allegorically, unremitting, ruthless industrial consumption. Ironically, Scrooge is portrayed initially as the very opposite of what the etymology of his name suggests (Ebenezer means "Stone of Help" in 1 Samuel 7:12-14 NRSV):

External heat and cold had little influence on Scrooge. No warmth could warm, no wintry weather chill him. No wind that blew was bitterer than he, no falling snow was more intent upon its purpose, no pelting rain less open to entreaty. Foul weather didn't know where to have him. The heaviest rain, and snow, and hail, and sleet could boast of the advantage over him in one respect. They often "came down' handsomely and Scrooge never did (Dickens, 2006, p.3).

Tiny Tim, Bob Cratchit's little son, is ailing as a direct consequence of his father's miserly wages from Ebenezer Scrooge, wages which permit very limited consumption. Malnourished and propping himself as he walks on crutches, he is visited by his father's employer during the second ghostly tour of Christmas Present. Stephanie Pappas (2012) quotes a physician, Dr. Chesney, who attributes Tiny Tim's condition to a combination of rickets and tuberculosis (Pappas, 2012). It is also to be understood from the text that Ebenezer Scrooge could help Tiny Tim (and thereby save his own soul) by means of establishing more evenly distributed consumption patterns including an increase of the wages of his clerk, Tiny Tim's father, as well as rendering himself open to more charity in the spirit of Christmas traditions. Ebenezer's reformation unlocks the true meaning of his name, the return to a sensitivity of the human condition seen as a miraculous Christmas re-territorialization of humanity in industrial England and suggests a recovery for Tiny Tim as his urban consumption increases. 
In her analysis of Dombey and Son (2009) and tuberculosis Katherine Byrne (2011) confirms Sontag's claims about tuberculosis being romantically associated with spirituality in the $19^{\text {th }}$ century and argues that with Dickens the social and moral consequences of consumer capitalism are pathological and manifest themselves in tuberculosis as "the disease of consumer society" (Byrne, 2011, p. 49). Dickens's city dwellers can, therefore, be seen as more spiritually advanced if consuming less, thus being either closer to death and God respectively such as Nell Trent (The Old Curiosity Shop), Paul Dombey (Dombey and Son) resulting from sickness (tuberculosis) or closer to God, but away from death in the event of self-imposed abstention (corporeal consumption with Amy Dorrit (Little Dorrit), Dora Spenlow (David Copperfield), Florence Dombey (Dombey and Son) $)^{2}$; thus this critic sees "Paul's tubercular decline as a triumph over society's attempts to assimilate him into the capitalist world, and his father's impatient desire to see him grow up" (Byrne, 2011, p. 53). Paul's and Nell's death scenes are among the most critically acclaimed and contested at the same time in Dickens and they reveal tuberculosis as consuming youth, growth, and future promise, but also as "a spiritual disease traditionally considered an affliction of the pure, the innocent and the young" (Byrne, 2011, p. 54).

The passages I have selected from Dickens's works by no means exhaust all his depictions of the disease, but they represent the emergence of a modern sensibility, one which views tuberculosis alternatively or simultaneously from the point of view of the investigating scientist and the fellow being; with Dickens, one is identical with the other. Dickens, perhaps more than any other Victorian writer, provides depiction of tuberculosis as an integral part of city consumption - the other end on the measuring scale of urban consumption, an approach also employed by the American modernist John Dos Passos in his Manhattan Transfer (2000) from 1925 and USA (1984) from 1930-1936. The White Plague (tuberculosis) is certainly the sentence of most unfit consumers of the metropolis - malnourished or lacking the skills for an adept urban consumer (Paul Dombey) languishing away. Dickens's depictions of the disease vary greatly - from vaguely suggesting its presence by referring to some of its symptoms as a wasting disease (Paul Dombey) to directly naming it as a common urban condition - the consumptive curate, or the worn-out woman in the last stage of consumption, exhausted by the disease and her family, etc. The English writer extends consumption as a disease to domestic animals, too, especially animals of burden as they are also consumed by the city by the way their owners consume them. In all the portrayals, the characters seem to have accepted their fate, including the donkey, a fact poignantly observed by Alex Tankard in

2. See Boev, H. (2021). Anorexia Mirabilis Decoded: Rereading Female Corporeal Consumption in Dickens's Angelic Daughters. Studies in Linguistics, Culture, and FLT, 9(1), 40-53. https://doi.org/10.46687/SILC.2021.v09i01.003 
Tuberculosis and Disabled Identity in Nineteenth Century Literature (2018), and so this critic, having referred to a similar acceptance in Jane Eyre (1997), asks: "Where are all the angry, blasphemous, bad consumptives in Victorian literature?" (Tankard, 2018, p. 2). This critic addresses the issue of a perceived lack of "medical realism" (p. 2), drawing our attention to the fact that often the writers depicted the tubercular sufferer dying, thus failing to portray the character's living with the disease (p. 2). She also highlights the aspects of what she calls "literary tuberculosis" (p. 2), as being different in its significance from what it meant for the sick in life. In its Victorian literary manifestations, as can be seen in the abovecited depiction that Dickens makes of Smike from Nicholas Nickleby, the spiritual aspect of the romantic portrayal is foregrounded.

Tuberculosis as a form of consumption in Dickens remains largely in the tradition of romantic poetry (the body consumed with passion within, the spirit longing to break free) when referring to a main character (city dweller) like Smike (Nicholas Nickleby) or Paul Dombey (Dombey and Son). In the case of Nell Trent (The Old Curiosity Shop) and Paul Dombey, it also represents their yearning for innocence and their refusal to be corrupted by city consumption. As Sontag claims, tuberculosis was considered a part of physical appearance (reduced energy and increased sensitivity) (Sontag, 2001, p. 54), and these consumptive looks became a mainstream lifestyle throughout the nineteenth century that excluded eating with appetite while sporting a suffering look (Sontag, 2001, p. 31). That way the city dwellers could always look more spiritual (melancholic and artistic), hence more in touch with their religious practices. The trick, then, was to have that look without having the disease, and that in turn required certain table manners with demonstrated abstention from excessive food consumption, which was to set up the image and example of modern table manners and physical looks. The Victorians passed on to the modernist period that followed the ideal of slim feminine figures and pale faces. More modernist less romantic and overtly ironic representations of the disease can be seen, perhaps surprisingly, in earlier works such as Sketches by Boz from 1836 and The Old Curiosity Shop from 1841, where Dickens remains truer to life having employed a journalist approach to portraying London and does not fail to capture the hidden duality of tuberculosis in its relationship to consumption, thus the haggard pale faces of the anonymous consumptive city dwellers (mainly women) stare back at the reader with their bulging eyes from deep sockets creating an anxious sensation of palpable suffering or, alternatively, a representative of the clergy could be comically portrayed as being afflicted with the disease, giving prevalence to his consumptive needs in the metropolis related to the inevitable mundane daily practices of the city resident. 


\section{References:}

(1843, November 10). The Newcastle Courant, Issue 8814, p.1. Newcastle-uponTyne, England.

(1849, March 31). The Northern Star and National Trades' Journal, Issue 597, p.1. Leeds, England.

(1860, March 25). Lloyd's Weekly Newspaper, Issue 905, p. 1. London, England.

Byrne, K. (2011). Tuberculosis and the Victorian literary imagination. New York: Cambridge University Press.

Boev, H. (2021). Anorexia mirabilis decoded: Rereading female corporeal consumption in Dickens's angelic daughters. Studies in Linguistics, Culture, and FLT, 9(1), 40-53. https://doi.org/10.46687/SILC.2021.v09i01.003.

Boev, H. (2011). De-teritorrialization and re-territorialization in Little Nell's death-bed scene - Deconstructing Little Nell in The Old Curiosity Shop by Charles Dickens. Retrieved July 23, 2021, from https://victorianweb.org/ authors/dickens/boevl.html.

Boev, H. (2013). Modern(ist) portrayals of the city in Dickens and Dos Passos: Similarities, differences, continuities. Sofia: Izida.

Brontë, Ch. (1997). Jane Eyre. Ware: Wordsworth Editions Ltd.

Dickens, Ch. (2006). A Christmas Carol. the Project Gutenberg, \#19337.

Dickens, Ch. (1998). David Copperfield. London: The Electric Book Company Ltd.

Dickens, Ch. (2009). Dombey and Son. Jakarta: The Econarch Institute.

Dickens, Ch. (1993). Great Expectations. Oxford: Clarendon Press.

Dickens, Ch. (1868). Little Dorrit. New York: Books.

Dickens, Ch. (1990). Nicholas Nickleby. Oxford: Oxford University Press.

Dickens, Ch. (2009). Sketches by Boz. Jakarta: The Econarch Institute.

Dickens, Ch. (1907). The old curiosity shop. London: J. M. Dent \& Sons, Ltd.

Dos Passos, J. (2000). Manhattan transfer. Boston. New York: Houghton Mifflin Company.

Dos Passos, J. (1984). USA: The 42nd parallel, nineteen nineteen, the big money. New York: Houghton Mifflin Company.

Dumas-fils, A. (2016). La Dame aux Camélias. New York: CreateSpace Independent Publishing.

Mitchell, S. (2009). Daily life in Victorian England. London: Greenwood Press.

Pappas, S. (2012). Dickensian diagnosis: Tiny Tim's symptoms decoded in $A$ Christmas Carol by Charles Dickens. Retrieved 23 July, 2021, from https:// www.livescience.com/18802-dickens-tiny-tim-diagnosis.html. 
Robinson, A. (2004). Imagining London, 1770-1900. New York: Palgrave Macmillan.

Sontag, S. (2001). Illness as metaphor and AIDS and its metaphors. London: Picador.

Tankard, A. (2018). Tuberculosis and disabled identity in nineteenth century literature. London: Palgrave Macmillan.

Veblen, T. (2007). The theory of the leisure class. New York: Oxford University Press. 